\title{
Attitudes to time and coping-strategies of farming entrepreneurs
}

\author{
Vlada Pishchik $^{1^{*}}$ \\ ${ }^{1}$ Don State Technical University, 1, Gagarin Sq., 344003, Rostov-on-Don, Russia
}

\begin{abstract}
Farmers and especially their psychological state are not often objects of research. We used the following methods: the questionnaire "Attitudes to time" by Nutten (in Muzdybayev's modification); the questionnaire SACS - "Strategies for overcoming stressful situations" (Hobfoll, 1994); the questionnaire of problems assessment in the activities of the farmers; the questionnaire "Crisis", developed by us. The questionnaire "Crisis" was used to identify three groups of level of wellbeing. The sample consisted of farmers: 50 people. The results showed that the attitudes to time of young farmers have a positive, interesting, full of hope past; the present is negative, terrible, unsuccessful, significant; the future is positive, full of hope, active and saturated. The attitudes to time of older farmers are the following: the positive, pleasant, difficult, eventful past; the present is meaningful, positive, hopeful; the future is interesting, positive, bright, full of hope. The level of well-being in both groups is estimated at the average one. Coping strategies in the group of young farmers are - getting in touch, in the group of senior managers - indirectactions; in both groups - finding social support. The assessment of the problems of farming activity revealed two key problems - insufficient funds and lagging modernization.
\end{abstract}

\section{Introduction}

There are many problems in farming by Russian farmers. Farmers cannot fully use the land allocated to them, as there are no funds for purchasing of equipment, material and technical resources and payment for services. The main difficulty for novice farmers is the lack of initial capital. There are no business plans in most farms. There is problem of pricing and ensuring the profitability of farm production. The structures of agricultural consumer cooperation designed to make farms more competitive are not well developed. There is a tendency of reducing farms. The number of farming enterprises in Russia has decreased over the past 10 years, although the authorities in the regions are making great efforts to develop the agro-industrial industry [1,2]. In this regard, it is relevant to study the psychological state of farmers in the current situation of economic instability and the consequences of the pandemic as the former seldom becomes the object of research.

The available researches of farmers show that they are very resistant to financial crises [3]. Both socio-psychological and socio-economic factors influence farmers' decision-making [4].

${ }^{*}$ Corresponding author: vladaph@yandex.ru 
Adler, Christley, Campe (2019) showed that attitudes indicating a higher level of technical knowledge, attachment to problems, awareness of responsibility, perception of control over the situation, improvement of human-animal relations or a positive assessment of the benefits of management decisions, as a rule, have a beneficial effect on the results of their activities [5]. It has been demonstrated that the personality traits "Agreeableness" and "Conscientiousness" contribute to the improvement of the farmer's work, while "Neuroticism" has a negative impact. There are differences in the mentality of rural and urban populations. Traditional mentality was less expressed in urban and more expressed in rural Russian respondents, but its predominance is not so significant. In fact, the rural population is changing today.

The relevance of the problem determined the purpose of the study - to differentiate attitudes to time, coping strategies and attitudes to the well-being of entrepreneurs in farming.

\section{Materials and methods}

The sample of the study were farmers from Salsky, Kagalnitsky districts, Southern region of Russia. We identified two groups of respondents: farmers with work experience from 3 to 15 years: 50 people and farmers with work experience from 15 to 25 years: 48 people. All of them are male.

We used the following methods: the questionnaire "Attitudes to time" by Nutten (in modification of Muzdybayev, 2000) [6]; the questionnaire SACS - "Strategies for overcoming stressful situations" (Hobfoll, 1994) (adaptation of Vodopyanova, 2009) [7]; the questionnaire of problems assessment in the activities of the farmers; the questionnaire "Crisis", developed by us. The questionnaire "Crisis" was used to identify three groups according to the level of well-being: low, medium, high.

The description of the methods. The questionnaire "Attitudes to time" by Nuttin (2014). Time evaluations were given on a 7-point system, where 7 is the highest positive score, 4 is neutral, and 1 is extremely negative. The Concept Nuttin (2014) differentiates time perspective, time orientation and time attitude (relation to time). The scale includes three indices of attitude to time: "emotional attitude", "value attitude" and "personal control" of time. SACS questionnaire - "Strategies for coping with stressful situations"(Hobfoll, 1994). It is designed to identify preferred strategies for overcoming difficult (stressful) situations. The questionnaire for assessing problems in the activities of farmers included 7 items: 1 . Low level of infrastructure development; 2 . The problem of rural poverty associated with low assessment of agricultural labor; 3. Low availability of qualified personnel; 4. Difficult demographic situation in rural areas; 5. Loss of own working capital; 6. Uncompetitiveness of agricultural industries; 7. Lagging modernization and technical renewal of the agricultural sector. Each problem was evaluated on a 5-points scale. The bigger the problem, the higher the score.

The SACS questionnaire - "Strategies for coping with stressful situations" (Hobfoll, 1994) consists of 54 statements, to which the respondent answers on a 5-point system. In accordance with the key, the sum of points for each line is calculated, which reflects the degree of preference for a particular behavior model in a difficult (stressful) situation. The questionnaire contains 9 models of overcoming behavior: 1) assertive actions; 2) entering into social contact; 3) seeking for social support; 4) cautious actions; 5) impulsive actions; 6) avoidance; 7) manipulative (indirect) actions; 8) antisocial actions; 9) aggressive actions.

The "Crisis" questionnaire was based on a preliminary list of farmers' problems. The most significant problems seemed to be the following: 1. Low level of infrastructure development, 2. The problem of rural poverty associated with low assessment of agricultural labor, 3. Low availability of qualified personnel, 4.Difficult demographic situation in rural areas, 5. Loss of own working capital, 6.Uncompetitiveness of agricultural 
industries, 7. Lagging modernization and technical renewal of the agricultural sector. The respondents had to rate the problems from 1 to 5 .

We put forward the following assumptions: H1 - you can find differences in attitudes to time, coping strategies between young and older farmers; H2 - there are similarities in the vision of the problems of young and older farmers.

\section{Results}

Let's consider the data for a group of young farmers with work experience from 3 to 15 years (Table 1).

Table 1. Attitudes to time of farmers entrepreneurs with work experience from 3 to 15 years.

\begin{tabular}{|c|c|c|c|c|c|c|c|c|c|}
\hline \multirow[b]{2}{*}{$\begin{array}{l}\text { Attitudes to } \\
\text { time }\end{array}$} & \multicolumn{3}{|c|}{ Present } & \multicolumn{3}{|c|}{ Past } & \multicolumn{3}{|c|}{ Future } \\
\hline & $\begin{array}{l}\stackrel{0}{0} \\
0 \\
0\end{array}$ & 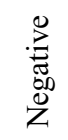 & $\begin{array}{l}\bar{\pi} \\
\text { 苛 } \\
\text { Z }\end{array}$ & $\begin{array}{l}\stackrel{D}{Z} \\
0 \\
0 \\
0\end{array}$ & 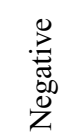 & $\begin{array}{l}\bar{\pi} \\
\overline{0} \\
\bar{Z}\end{array}$ & $\begin{array}{l}: \\
: \\
0 \\
0 \\
0\end{array}$ & 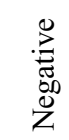 & 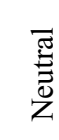 \\
\hline Safe - scary & 0 & 2,7 & 0,3 & 5 & 0,2 & 0,4 & 3,8 & 0,4 & 0,7 \\
\hline $\begin{array}{l}\text { Pleasant - } \\
\text { unpleasant }\end{array}$ & 0 & 1,7 & 1 & 5 & 0 & 0,6 & 3,3 & 0,1 & 1,5 \\
\hline Bright - dark & 0 & 1,3 & 1,5 & 4,9 & 0,1 & 0,7 & 3,9 & 0,5 & 0,7 \\
\hline $\begin{array}{l}\text { Hopeful - } \\
\text { hopeless }\end{array}$ & 0 & 2 & 0 & 6,6 & 0,1 & 0,3 & 5,5 & 0,3 & 0,2 \\
\hline Fine - awful & 0 & 1,6 & 1,5 & 5 & 0 & 0,7 & 3,7 & 0,3 & 1,1 \\
\hline Easy - difficult & 0,6 & 2,1 & 0,7 & 4,5 & 0,4 & 0,6 & 2,7 & 0,6 & 1,1 \\
\hline $\begin{array}{l}\text { Successful - } \\
\text { unsuccessful }\end{array}$ & 0 & 2,9 & 0 & 3,8 & 0,2 & 0,8 & 4,2 & 0,3 & 1 \\
\hline $\begin{array}{l}\text { Meaninful - } \\
\text { meaninless }\end{array}$ & 1,9 & 1,6 & 0,7 & 4,9 & 0,2 & 0,6 & 5,3 & 0,1 & 0,4 \\
\hline Mine - alien & 0 & 1,4 & 2,2 & 5,2 & 0 & 0,7 & 4,4 & 0,1 & 0,8 \\
\hline $\begin{array}{l}\text { Interesting - } \\
\text { boring }\end{array}$ & 0 & 1 & 2,7 & 6,6 & 0,2 & 0,2 & 4,2 & 0,2 & 1 \\
\hline $\begin{array}{l}\text { Fast-passing - } \\
\text { long-drawn }\end{array}$ & 0 & 2,2 & 0 & 6 & 0,3 & 0,2 & 5,8 & 0,2 & 0,8 \\
\hline $\begin{array}{l}\text { Active - } \\
\text { passive }\end{array}$ & 1,7 & 1,3 & 0 & 5,1 & 0 & 0,2 & 5,9 & 0,3 & 1 \\
\hline $\begin{array}{l}\text { Eventful - } \\
\text { eventless }\end{array}$ & 0 & 1,5 & 2 & 5,2 & 0,1 & 0,4 & 5,9 & 0,2 & 1,1 \\
\hline $\begin{array}{l}\text { Significant - } \\
\text { insignificant }\end{array}$ & 0 & 3 & 0 & 5,3 & 0 & 0,6 & 5,3 & 0 & 0,6 \\
\hline Free - non-free & 0 & 2,7 & 0,4 & 4,2 & 0,1 & 0,8 & 5,5 & 0,3 & 1,1 \\
\hline
\end{tabular}

The present is described by respondents with less work experience as a negative process. As it can be seen from Table 1, the present time is described by the following epithets: scary, unpleasant, hopeless, terrible, difficult and unsuccessful, long-drawn, insignificant, non-free. Attitudes to the present look neutral according to the criteria: bright -dark, mine-alien, interesting-boring, eventful-eventless. The present as a positive process was described by respondents according to the following criteria: meaningful, active. 
Against the background of such data about the present, it is interesting to see the attitudes of respondents to the past. They described it exclusively as a positive process: safe, pleasant, bright, hopeful, nice, easy, successful, meaningful, mine, interesting, fastpassing, active, eventful, significant, free.

The future is also viewed as positive by respondents. It is evaluated by them as: safe, pleasant, bright, hopeful, fine, easy, successful, meaningful, mine, interesting, fast-passing, active, eventful, significant, free.

Let's consider the results for a group of older farmers with work experience from 15 to 25 years (Table 2 ).

Table 2. Attitudes to time of farmers entrepreneurs with work experience from 15 to 25 years.

\begin{tabular}{|c|c|c|c|c|c|c|c|c|c|}
\hline \multirow[b]{2}{*}{$\begin{array}{l}\text { Attitudes to } \\
\text { time }\end{array}$} & \multicolumn{3}{|c|}{ Present } & \multicolumn{3}{|c|}{ Past } & \multicolumn{3}{|c|}{ Future } \\
\hline & $\begin{array}{l}\stackrel{0}{0} \\
0 \\
0 \\
0\end{array}$ & 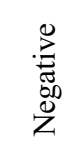 & 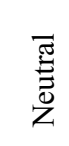 & $\begin{array}{l}\stackrel{2}{0} \\
0 \\
0 \\
0\end{array}$ & 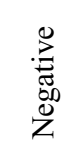 & $\begin{array}{l}\bar{\pi} \\
\bar{\Xi} \\
\bar{z}\end{array}$ & $\begin{array}{l}\stackrel{0}{0} \\
0 \\
0 \\
0\end{array}$ & $\begin{array}{l}\stackrel{0}{D} \\
\stackrel{0}{0} \\
\stackrel{0}{0}\end{array}$ & 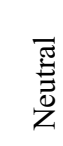 \\
\hline Safe - scary & 0 & 0,1 & 2,8 & 3,5 & 1,3 & 1 & 4,1 & 0,9 & 5,3 \\
\hline $\begin{array}{l}\text { Pleasant - } \\
\text { unpleasant }\end{array}$ & 5,9 & 3 & 1,6 & 8,3 & 3,2 & 6,1 & 5,5 & 3,2 & 4,8 \\
\hline Bright - dark & 1,6 & 2,3 & 5,5 & 5,1 & 4,1 & 8 & 6,7 & 5,9 & 3,1 \\
\hline $\begin{array}{l}\text { Hopeful - } \\
\text { hopeless }\end{array}$ & 7 & 5,1 & 3,8 & 6,7 & 2,5 & 3 & 7,6 & 1,1 & 1,8 \\
\hline Nice - awful & 1 & 3,1 & 6,6 & 5 & 2,2 & 6,9 & 4,6 & 3,2 & 5,9 \\
\hline $\begin{array}{c}\text { Easy- } \\
\text { difficult }\end{array}$ & 1,6 & 4,3 & 7,7 & 8,6 & 0 & 3,2 & 0 & 4,7 & 7,5 \\
\hline $\begin{array}{c}\text { Successful - } \\
\text { unsuccessful }\end{array}$ & 3,6 & 4,7 & 7 & 6,6 & 3 & 4,7 & 6 & 3,2 & 4,4 \\
\hline $\begin{array}{l}\text { Meaninful - } \\
\text { meaninless }\end{array}$ & 7,7 & 1,6 & 2,2 & 7,5 & 0,1 & 3 & 4,6 & 2,2 & 5,8 \\
\hline Mine - alien & 8,9 & 0 & 1,5 & 7,9 & 5,7 & 4,8 & 7,7 & 0 & 0 \\
\hline $\begin{array}{l}\text { Interesting - } \\
\text { boring }\end{array}$ & 6,2 & 3 & 3,9 & 4,5 & 2,8 & 7,6 & 7,6 & 1,1 & 3,8 \\
\hline $\begin{array}{c}\text { Fast-passing - } \\
\text { long-drawn }\end{array}$ & 6,6 & 2,2 & 7,5 & 3,9 & 2,1 & 6,8 & 7,1 & 2,8 & 2,1 \\
\hline $\begin{array}{l}\text { Active - } \\
\text { passive }\end{array}$ & 0,3 & 2,1 & 4,9 & 5,4 & 3,1 & 2,2 & 5,9 & 2,6 & 4,9 \\
\hline $\begin{array}{l}\text { Eventful - } \\
\text { eventless }\end{array}$ & 6,3 & 4,7 & 1,2 & 7 & 2,7 & 0,5 & 6,8 & 2,3 & 7,7 \\
\hline $\begin{array}{l}\text { Significant - } \\
\text { insignificant }\end{array}$ & 3,1 & 4,1 & 7 & 6,3 & 2,1 & 3,3 & 2,8 & 4,9 & 6,6 \\
\hline $\begin{array}{l}\text { Free }- \text { non- } \\
\text { free }\end{array}$ & 4,9 & 2,1 & 1,3 & 3,7 & 2,3 & 0,1 & 5,2 & 4,1 & 7,7 \\
\hline
\end{tabular}

As it can be seen in Table 2, entrepreneurs with work experience from 15 to 25 years described the present time as a positive process. It was evaluated positively according to the following criteria: pleasant, hopeful, meaningful, mine, interesting, eventful, free. Neutrally it is evaluated by the following criteria: safe-scary, bright-dark, nice-awful, easy-difficult, successful-unsuccessful, fast-passing-long-drawn, active-passive, significant-insignificant.

The past time is evaluated exclusively as a positive process. It is described by respondents as: safe, pleasant, hopeful, easy, successful, meaningful, mine, active, eventful, 
significant, free. It is neutrally evaluated only on the criteria: bright - dark, nice-awful, interesting-boring, fast-passing - long-drawn.

The future time is evaluated rather as a positive process. It seems to respondents pleasant, bright, hopeful, fast-passing, active. It is neutrally evaluated by the following criteria: safe-scary, nice-awful, easy-difficult, meaningful-meaningless, eventful eventless, significant - insignificant, free - non-free.

The overall indicator in relation to time in the past, present and future determined differences in groups $(\mathrm{U}=135.0, \mathrm{p}=0.033)$.

Let's move from the analysis of differential estimates to the study of more generalized attitudes to the past, present and future. The analysis will be carried out according to three criteria: the affective perception of time, the value attitude to it and the ability of the individual to control and manage his time. According to Table 3, it can be seen that the present is perceived by respondents with little work experience as neutral in emotional terms, neutral in value terms, negative in personal control. The past is evaluated positively in terms of emotional attitude, value attitude, and personal control. The future is also evaluated positively in emotional, value, and personal control.

Table 3. Attitudes to time of farmers entrepreneurs with work experience from 3 to 15 years.

\begin{tabular}{|c|c|c|c|c|c|c|c|c|c|}
\hline \multirow{2}{*}{$\begin{array}{c}\text { Attitudes to } \\
\text { time }\end{array}$} & \multicolumn{3}{|c|}{ To present } & \multicolumn{3}{c|}{ To past } & \multicolumn{3}{c|}{ To future } \\
\cline { 2 - 11 } & $\begin{array}{c}\text { Posi } \\
\text { tive }\end{array}$ & $\begin{array}{c}\text { Negati } \\
\text { ve }\end{array}$ & $\begin{array}{c}\text { Neut } \\
\text { ral }\end{array}$ & $\begin{array}{c}\text { Posi } \\
\text { tive }\end{array}$ & $\begin{array}{c}\text { Negati } \\
\text { ve }\end{array}$ & $\begin{array}{c}\text { Neutra } \\
\text { l }\end{array}$ & $\begin{array}{c}\text { Posi } \\
\text { tive }\end{array}$ & $\begin{array}{c}\text { Negati } \\
\text { ve }\end{array}$ & Neutral \\
\hline emotional & 5,3 & 4,7 & $\mathbf{1 0 , 7}$ & 17 & 0 & 3,4 & 18,8 & 2,2 & 5,4 \\
\hline value & $\mathbf{6 , 8}$ & 4,8 & 8,6 & $\mathbf{1 9 , 3}$ & 1 & 1,8 & $\mathbf{1 9 , 6}$ & 0,6 & 5,4 \\
\hline $\begin{array}{c}\text { personal } \\
\text { control }\end{array}$ & 5,7 & 6,4 & 7 & 16,1 & 0,6 & 4,3 & 18,3 & 0,8 & 6,2 \\
\hline
\end{tabular}

Let's consider the results for a group of farmers with longer work experience (Table 4).

Table 4. Attitudes to time of farmers entrepreneurs with work experience from 15 to 25 years.

\begin{tabular}{|c|c|c|c|c|c|c|c|c|c|}
\hline \multirow{2}{*}{$\begin{array}{c}\text { Attitudes to } \\
\text { time }\end{array}$} & \multicolumn{3}{|c|}{ To present } & \multicolumn{3}{c|}{ To past } & \multicolumn{3}{c|}{ To future } \\
\cline { 2 - 11 } & $\begin{array}{c}\text { Posi } \\
\text { tive }\end{array}$ & $\begin{array}{c}\text { Negat } \\
\text { ive }\end{array}$ & $\begin{array}{c}\text { Neutr } \\
\text { al }\end{array}$ & $\begin{array}{c}\text { Positi } \\
\text { ve }\end{array}$ & $\begin{array}{c}\text { Neg } \\
\text { ativ } \\
\text { e }\end{array}$ & $\begin{array}{c}\text { Neutr } \\
\text { al }\end{array}$ & $\begin{array}{c}\text { Positi } \\
\text { ve }\end{array}$ & $\begin{array}{c}\text { Negat } \\
\text { ive }\end{array}$ & Neutral \\
\hline emotional & 7,3 & 5,2 & 7,9 & 4,3 & 6,5 & 7,7 & 18,3 & 0,6 & 5,4 \\
\hline value & 5,7 & 10,8 & 4,3 & 8,6 & 2,2 & 9,9 & 19,6 & 5,7 & 6,8 \\
\hline $\begin{array}{c}\text { personal } \\
\text { control }\end{array}$ & 1,3 & 4,8 & 7,6 & 21,9 & 13,6 & 16,7 & 5,7 & 5,3 & 6,2 \\
\hline
\end{tabular}

According to Table 4, it can be said that the present is evaluated by respondents with longer work experience as neutral in emotional terms, negative in value terms, and neutral in personal control time. The past is evaluated neutral in emotional, value attitude, and positive with personal control attitude. The future is evaluated positively in emotional attitude, positively in a value attitude, and neutrally in personal control attitude.

.Let's consider the financial satisfaction of farmers entrepreneurs. These groups were identified at different times: before the fall of 2008 (before the global economic crisis) and at the present time. The results are presented in Table 5. 
Table 5. Levels of welfare of farmers entrepreneurs.

\begin{tabular}{|l|l|l|l|l|}
\hline \multirow{2}{*}{ Levels of welfare } & \multicolumn{2}{|c|}{ Autumn 2008 } & \multicolumn{2}{c|}{ Present time } \\
\cline { 2 - 5 } & $\begin{array}{c}\text { from } 3 \text { to } 15 \\
\text { years }\end{array}$ & $\begin{array}{c}\text { from } 15 \text { to } 25 \\
\text { years }\end{array}$ & $\begin{array}{c}\text { from } 3 \text { to } 15 \\
\text { years }\end{array}$ & $\begin{array}{c}\text { from } 15 \text { to } 25 \\
\text { years }\end{array}$ \\
\hline High & 0,1 & 0,1 & 0,1 & 0,3 \\
\hline Average & 0,8 & 0,8 & 0,4 & 1 \\
\hline Low & 0,2 & 0,5 & 1 & 0,3 \\
\hline
\end{tabular}

Thus, the group of respondents with work experience from 3 to 15 years, in the autumn of 2008, showed the average level of well-being. The low level of well-being is currently characterized by the situation of crisis, lack of work, reduced wages, and dismissal.

In the autumn of 2008, the average level of well-being prevails among entrepreneurs with work experience from 15 to 25 years; at present, this group of respondents also shows the average level of well-being. Consequently, entrepreneurs with work experience from 15 to 25 years have an average level of well-being both before the global crisis and at the moment, which indicates the stability of the financial situation.

We also revealed the prevailing coping strategies of farmers entrepreneurs. For each subscale we calculated average values. The results of the study of entrepreneurs with work experience from 3 to 15 years are presented in Table 6 .

Table 6. Strategies for overcoming stressful situations of farmers entrepreneurs.

\begin{tabular}{|c|c|c|}
\hline \multirow{2}{*}{ Subscales } & \multicolumn{2}{|c|}{ Points } \\
\cline { 2 - 3 } & $\begin{array}{c}\text { from 3 to } 15 \\
\text { years }\end{array}$ & $\begin{array}{c}\text { from } 15 \text { to } \\
25 \text { years }\end{array}$ \\
\hline 1. Assertive actions & 22 & 24,2 \\
\hline 2. Entering into social contact & 24,6 & 24 \\
\hline 3. Seeking for social support & 25,3 & 26,5 \\
\hline 4. Cautious actions & 24,6 & 24,9 \\
\hline 5. Impulsive actions & 22,7 & 20,4 \\
\hline 6. Avoidance & 23,8 & 23,9 \\
\hline 7. Indirect actions & 24,2 & 25,8 \\
\hline 8. Antisocial actions & 23,7 & 24,4 \\
\hline 9. Aggressive actions & 7 & 24,7 \\
\hline
\end{tabular}

As it can be seen from Table 6, the following coping strategies prevail among farmers entrepreneurs with less experience: entering into social contact and seeking for social support. This suggests finding support from other people.

In the group of entrepreneurs with longer experience, the search for social support and indirect actions prevails. The significance of the difference in coping strategy in the indirect actions is $\mathrm{U}=179.0, \mathrm{p}=0.005$.

Thus, the search for social support dominates in both groups. Significant differences were found for this indicator $(\mathrm{U}=164.0, \mathrm{p}=0.033)$. Therefore, it can be concluded that respondents need the support of other people.

To study the problems of farmers entrepreneurs we used a questionnaire on the study of problems of farmers entrepreneurs. We calculated average values for each problem. The results of the study of entrepreneurs are presented in Table 7. 
Table 7. Problems of farmers entrepreneurs.

\begin{tabular}{|c|c|c|}
\hline \multirow{2}{*}{ Problems } & \multicolumn{2}{|c|}{ Points } \\
\cline { 2 - 3 } & $\begin{array}{c}\text { from 3 to } \\
\text { 15 years }\end{array}$ & $\begin{array}{c}\text { from 15 to } \\
25 \text { years }\end{array}$ \\
\hline 1. Low level of infrastructure development & 3,2 & 3,3 \\
\hline $\begin{array}{c}\text { 2. The problem of rural poverty associated with } \\
\text { low assessment of agricultural labor }\end{array}$ & 3,7 & 4,7 \\
\hline 3. Low availability of qualified personnel & 3,4 & 3,3 \\
\hline 4. Difficult demographic situation in rural areas & 2,9 & 3,1 \\
\hline 5. Loss of own working capital & 3,1 & 3,2 \\
\hline 6. Uncompetitiveness of agricultural industries & 3,4 & 3,2 \\
\hline $\begin{array}{c}\text { 7. Lagging modernization and technical renewal } \\
\text { of the agricultural sector. }\end{array}$ & 3,6 & 3,4 \\
\hline
\end{tabular}

As it can be seen from Table 7, the following results were obtained for the problems of farmers entrepreneurs for the group with low work experience: the problems of rural poverty received the greatest weight. The main factor of poverty is the low assessment of agricultural labor and the lag in the modernization and technical renewal of the agricultural sector. This is due to both the low profitability of producers and the state of agricultural engineering. In the group with a longer work experience, they received the highest points. We found significant differences in the indicator "Low level of infrastructure development" $(\mathrm{U}=58.0, \mathrm{p}=0.023)$.

Therefore, the problem of rural poverty associated with a low assessment of agricultural labor is most relevant for respondents. All this is connected with the situation of the global financial crisis.

\section{Discussion}

Attitudes to time are a reflection of the complex of feelings of an individual. Young farmers view the past and future of their lives as positive, and the present as negative. Their attitudes to time are associated with negative personal control. They are more futureoriented. Thus, the focus on the present indicates that values and opportunities are present now and their presence coincides in time. However, the values of the present time have not yet emerged, and the opportunities in it are minimal, or simply absent. Focusing on the past means that values and opportunities were present in it. We would like to note that the focus on the future means that values and opportunities are still ahead. This is comparable to the results of the FES Jugendstudien - an international youth research project in 2019 (https://www.fes.de/en/beitraege/youth-studies-russia) when 1,500 respondents aged 14 to 29 were surveyed. More than $43 \%$ of respondents are optimistic about the situation in the country which they think will improve in the next 10 years compared to today.

Farmers with longer work experience view their past, present and future positively. At the same time, they have a negative value attitude to the present and negative personal control over the past. They are more focused on the past. So, the focus on the present indicates that values and opportunities are not present at this time. Focusing on the past means that values and opportunities are still ahead. Future orientation means that there are values and opportunities.

This is comparable to the study by Ucar, Hasta, and Malatyali (2019) [8], who showed that increased control and reduced hopelessness were associated with increased life satisfaction among respondents. 
We think that attitudes to time determine the attitude and motivation to work. Among Ghana farmers, the authors found out that experimental measurements of trust, risk, and time preferences can predict preferences for contract attributes [9].

Another factor affecting the work of farmers is the attitude to the economic crisis. Heo, Lee, Park (2020) showed in a study that financial stress reduces life satisfaction, but farmers show a lower marginal effect than non-farmers [10]. The locus of control increases life satisfaction, but farmers show less marginal effect than non-farmers. Our study also shows that farmers rate well-being at an average level in crisis situations. Although young farmers rate their well-being as low. They underestimate results of their work and low technical equipment of work. This is a negative situation that they need to overcome.

Copings of young farmers are associated with social contacts and the search for support. Older farmers also turn to finding social support and to work around strategies for coping with difficult situations. This is confirmed in the study [11]. Social pressure has a strong impact on farmers, especially when compared to their own views. There is also an idea in the study [12] that farmers used different strategies to overcome weather shocks. Aniah, Kaunza-Nu-Dem, Ayembilla (2019) demonstrate strategies for adapting to climate change on farms, such as changing of planting times, using drought-resistant crop varieties, soil conservation strategies, based on farmers' knowledge passed down from generation to generation [13]. In the research work [14], the results showed that significant factors influencing the choice of strategies adaptation are the perceived status of soil fertility, the perception of land guarantees, access to knowledge dissemination services, and the age of heads of households.

Both young and older farmers are aware that there is a lag in the modernization and technical renewal of the agricultural sector. As it was noted in the work [15], most small farmers in Senegal avoid using modern cultivation technologies.

\section{Conclusions}

In combination with large agricultural enterprises and private subsidiary farms, farming can seriously improve the country's food security and improve the quality of life in rural areas.

The relevance of our research is determined by relatively infrequent Russian studies of the psychology of farmers, which are significant in our difficult times.

Our hypotheses were confirmed to be true in the study.

It was revealed that young farmers evaluate the present as negative, and look to the future with hope. Older farmers rate the perception of time as positive in the past and future, and the present as positive and neutral in equal parts.

Social support remains the traditional coping strategy of farmers.

The results of this study can be useful in the processes of regulating the state of stress resistance of farmers. Psychologists-consultants can use psychological future practices to normalize farmers who are experiencing the hardships of a crisis.

\section{References}

1. I. I. Doronina, V. N. Borobov, E. A. Ivanova, E. V. Gorynya, B. M. Zhukov, International Journal of Economics and Financial Issues, 6(1S), 295-299 (2016), https://www.scopus.com/inward/record.url?eid=2-s2.084979842427\&partnerID=40\&md5=0b1adaafe2c3c52881b6409f2a3b363c

2. A. E. Chernaya, M. N. Kabanenko, S. N. Ugrimova, IOP Conference Series: Earth and $\begin{array}{llll}\text { Environmental } & \text { Science, } & \text { 274(1), }\end{array}$ 
https://www.scopus.com/inward/record.url?eid=2-s2.0-

85067998869\&partnerID=40\&md5=7bb803facaceecf 2 fdcaf $9880 \mathrm{c} 4 \mathrm{dfe} 83$

3. W. Heo, J. M. Lee, N. Park, Journal of Rural Studies (2020), https://doi.org/10.1016/j.jrurstud.2020.08.053

4. E. M.B. Doran, A. Zia, S. E. Hurley, et al., Journal of Environmental Management, 276, 111304 (2020), https://doi.org/10.1016/j.jenvman.2020.111304

5. F. Adler, R. M. Christley, A. Campe, Journal of Dairy Science, 102(5), 3805-3824 (2019), https://doi.org/10.3168/jds.2018-15037

6. J. Nuttin, European Journal of Social Psychology, 15(3), 353-361 (1985), doi: $10.1002 /$ ejsp.2420150309

7. T. N. Banshchikova, M. L. Sokolovskii, V. A. Solomonov, E. A. Fomina, Modern Journal of Language Teaching Methods, 9(1), 438-452 (2019, DOI: 1026655/mjltm.2019.1.1.

8. J. Nuttin, Future Time Perspective and Motivation: Theory and Research Method (Louvain Psychology Series Studia Psychologica. Studia psychologica) (Psychology Press, 2014), https://books.google.ru/books?id

9. G. K. Ucar, D. Hasta, M. K. Malatyali, Personality and Individual Differences, 143, 68-73 (2019), https://doi.org/10.1016/j.paid.2019.02.021

10. S. Fischer, M. Wollni, Food Policy, 81, 67-81 (2018), https://doi.org/10.1016/j.foodpol.2018.10.005

11. G. M. L. Castillo, A. E. M. Wollni, Agricultural Water Management, 243, 106524 (2021), https://doi.org/10.1016/j.agwat.2020.106524

12. A. Hussain, J. A. Memon, S. Hanif, Weather and Climate Extremes, 30, 100288 (2020), https://doi.org/10.1016/j.wace.2020.100288

13. P. Aniah, M. K. Kaunza-Nu-Dem, J. A. Ayembilla, Heliyon, 5(4), e01492 (2019), https://doi.org/10.1016/j.heliyon.2019.e01492

14. A. Alemayehu, W. Bewket, Environmental Development, 24, 77-85 (2017), https://doi.org/10.1016/j.envdev.2017.06.006

15. S. Bukchin, D. Kerret, Heliyon, 6(8), e04694 (2020), https://doi.org/10.1016/j.heliyon.2020.e04694 